Article Type: Research Paper

\title{
Value Relevance of IFRS Adoption in ASEAN- 5 Countries: Does Presentation Matters?
}

\author{
Aria Farah Mita ${ }^{1 *}$, Sylvia Veronica Siregar ${ }^{2}$, Viska Anggraita ${ }^{3}$, and \\ Fitriany Amarullah ${ }^{4}$
}

AFFILIATION:
1234 Department of Accounting,
Faculty of Economics and Business, Universitas Indonesia, Jakarta, Indonesia.

\section{*CORRESPONDENCE:}

aria.farahmita@ui.ac.id

\section{THIS ARTICLE IS AVAILABLE IN:}

http://journal.umy.ac.id/index.php/ai

DOI: 10.18196/jai.2103165

\section{CITATION:}

Mita, A. F., Siregar, S. V., Anggraita, V., \& Amarullah, F. (2020). Value Relevance of IFRS Adoption in ASEAN-5 Countries: Does Presentation Matters?. Journal of Accounting and Investment, 21(3), 570-579.

\section{ARTICLE HISTORY}

Received:

30 June 2020

Reviewed:

01 July 2020

Revised:

15 July 2020

Accepted:

29 Aug 2020

\begin{abstract}
:
Research aims: This study discusses a recent development in adopting the International Financial Reporting Standard (IFRS) in ASEAN. The objective of this study is to examine the value relevance of the Other Comprehensive Income (OCI) after the International Accounting Standard (IAS 1) revision about the financial statements' presentation. This study primarily examines whether the relocation of the $\mathrm{OCl}$ from the Statement of Changes in Owners' Equity to the Statement of Comprehensive Income increases the value relevance.

Design/Methodology/Approach: This study compared the value relevance of other comprehensive income $(\mathrm{OCI})$ one year before and after the adoption of IAS 1 in each country. The study focused on ASEAN 5 countries: Indonesia, Malaysia, Philippine, Singapore, and Thailand.

Research findings: The study's result found that $\mathrm{OCI}$ had higher value relevance after the adoption of IAS 1.

Theoretical contribution/Originality: This study extends previous studies around IFRS adoption, mostly focused on European countries. The study of IFRS adoption in ASEAN countries is limited. This study presents a unique setting since most of the Countries in ASEAN adopted IAS 1 not in the same year as the year enacted by the IASB. This study contributes to the recent development in accounting standards, showing that IAS No. 1 adoption as part of the IFRS adoption in ASEAN will increase the financial statement's value relevance.

Practitioner/Policy implication: This study implies for the Practitioner and Policymakers that the IFRS adoption's benefits aimed to improve the financial reports' quality, so users can more easily and readily process information about company performance.
\end{abstract}

Research limitation/Implication: This study only focused on total OCI. This study did not analyze the impact of revised IAS 1 adoption for each item of OCl, such as available for sale component, revaluation surplus, or translation component. The result is consistent with the IFRS adoption's proponent that the IAS 1 revision will increase the financial statement's usefulness.

Keywords: International Accounting Standard; Comprehensive Income; Earnings Quality; Value Relevance

\section{Introduction}

This research is motivated by the IAS 1 revision in 2008 regarding the Financial Statements' Presentation, which is effective since 1 January 2009. Revised IAS 1 aims to improve information quality through the structure, content, and presentation of Financial Statements that are easier to understand and more useful for investors. This research focuses 


\author{
Mita, Siregar, Anggraita, \& Amarullah \\ Value Relevance of IFRS Adoption in ASEAN-5 Countries: Does Presentation Matters?
}

on ASEAN 5 countries: Indonesia, Malaysia, the Philippine, Singapore, and Thailand, which have only recently begun an extensive convergence of the international accounting standard (hereinafter IFRS) in the last decade. Accounting information is considered valuable to investors if the information has value relevance, i.e., providing relevant and useful information to investors as a basis for making investment decisions. Whether the revised IAS 1's purpose has been achieved remains unanswered for ASEAN countries.

The financial statements' presentation regulates the provisions of the financial statements' elements, how information is grouped and aggregated, the order in which they are presented, and the location where the information is presented. Provisions regarding financial statements' presentations are regulated in IAS 1 and are intended to make financial information useful to users. The consideration of how the presentation is and the location where the information presented in the financial statements is based on the perspective that the information will be easier to process and useful to the users if organized or presented in a grouping and the available location. For example, to calculate financial ratios and to make it easy for users to understand.

The most significant revision in IAS 1 is presenting other comprehensive income $(\mathrm{OCI})$ in a separate section included in the Comprehensive Income Statement. According to the revised IAS 1, the $\mathrm{OCI}$ is presented in a different location. Before the revision, $\mathrm{OCI}$ was presented on a Statement of Changes in Equity separate from its performance information. The concept of companies' earning is all-inclusive, meaning that all transactions increase the shareholder's capital that does not come from the owner's capital deposit. Therefore, revised IAS 1 aims to make it easier for investors to use company performance information using a readily bottom line of the comprehensive income. Whether the IAS 1 revision causes changes in the OCI presentation's location will increase the value relevance remains to be questioned. The phenomena of the financial information's presentation have been attractive to the researcher, but the study which focuses on the IAS 1 revision in ASEAN countries as IFRS adopters is very limited. Prior research has indicated that the locations where financial information was presented would have a different value relevance for investors (Maines \& McDaniel (2000); Mechelli and Cimini (2014); Khan and Bradbury (2014)). Hirst and Hopkins (1998) found that individual investors were better at estimating prices when other comprehensive income information was reported in the Income Statement than in the Statement in Changes in Equity. The bottom line presented in the Comprehensive Income Statement made investors easier in understanding all transactions' impact that leads to changes in capital resulted from the company's performance.

Based on the above-identified research gap, the purpose of this research is to test whether the $\mathrm{OCl}$ after IAS 1 revision has higher value relevance for investors. This research promotes recent issues regarding IFRS adoption's benefits. Previous studies have focused on the European Union (EU) countries as they first adopted the IFRS. This study compares the value relevance of the $\mathrm{OCI}$ in one year before and after adopting IAS 1 in each country. This study presents a unique setting since most of the countries in ASEAN adopted IAS 1 not in the same year as the year enacted by the IASB. This study 


\author{
Mita, Siregar, Anggraita, \& Amarullah \\ Value Relevance of IFRS Adoption in ASEAN-5 Countries: Does Presentation Matters?
}

contributes to the recent development in accounting standards, showing that IAS 1 adoption as part of the IFRS adoption in ASEAN will increase the financial statement's value relevance. Therefore, this research is expected to contribute as empirical evidence regarding one of the revised accounting standards' impacts as feedback IFRS convergence measures taken by the Financial Accounting Standards Board in each of the five ASEAN countries. The quality of financial accounting standards determines the Financial Statements' quality. This research is essential as feedback on efforts to improve the quality of financial statements, which is essential in realizing the integration of capital markets in ASEAN. One of the envisions of the ASEAN Economic Community is the realization of the integrated capital market in ASEAN. The higher the financial statements' quality, the higher accuracy and transparency will be to better allocate their capital efficiently. Better capital allocation will promote an efficient market and support the capital market's integration.

This paper is divided into six sections. First is the introduction, which tells about the background and the study's objective. Secondly is the literature review and hypothesis. The third part is the research methodology, and the fourth is the study's results. Moreover, the fifth section is a discussion and the result's analysis, and the last section is the conclusion.

\title{
Literature Review and Hypotheses Development
}

This section contains theoretical underpinning and literature references about previous research related to the topic and highlights a research gap. It is highly recommended that research Goncharov and Hodgson (2011) examine whether it is necessary to separate the operating profit and other comprehensive income $(\mathrm{OCI})$ in the financial statements. The results showed a need to separate operating income presentation and other comprehensive income $(\mathrm{OCl})$ presentation. Operating income as an appropriate decision matrix needs to be presented separately with $\mathrm{OCl}$ that is not yet realized. Jones and Smith (2011) compared OCl components and special items (SI). The accounting treatment of the regime studied by Jones and Smith (2011) revealed that SI was immediately recognized in the current profit, while the $\mathrm{OCl}$ was being postponed until realized. Jones and Smith's results discovered that both $\mathrm{SI}$ and $\mathrm{OCI}$ had value relevance.

Khan and Bradbury (2014) uncovered that the comprehensive (Total Comprehensive Income, hereinafter $\mathrm{TCl}$ ) profit was more volatile than net income. $\mathrm{TCl}$ correlated with market risk measurement (beta and standard deviation return). The finding indicated that $\mathrm{TCl}$ had risk relevance. Nevertheless, Khan and Bradbury found that comprehensive income incremental to net income volatility was not correlated with market risk and was not valued (not correlated with stock prices). Besides, research from Mechelli and Cimini (2014) examined the relative and incremental value relevance for Total Comprehensive Income $(\mathrm{TCl})$ and Other Comprehensive Income $(\mathrm{OCl})$ in listed companies in Europe after the International Accounting Standard (IAS 1) revised's implementation. IAS 1 revised requires the company to present a statement of comprehensive income $(\mathrm{SOCl})$ in which Net Income (NI) components and $\mathrm{OCl}$ components are disclosed separately. The results 


\author{
Mita, Siregar, Anggraita, \& Amarullah \\ Value Relevance of IFRS Adoption in ASEAN-5 Countries: Does Presentation Matters?
}

demonstrated that $\mathrm{NI}$ had higher value relevance than Total Comprehensive Income (TCl), although $\mathrm{OCl}$ in one period provided additional relevant information than $\mathrm{NI}$ information and book value. However, the OCl's total coefficient had a smaller value than NI. It indicated that a separate Statement of Comprehensive Income (SOCl) did not increase $\mathrm{TCl}$ and $\mathrm{OCl}$ values relevance. In addition, Maines and McDaniel (2000) investigated whether and how alternative presentation formats affected nonprofessional investors' processing of comprehensive-income information, specifically disclosing the volatility of unrealized gains on available-for-sale marketable securities.

The argument that supports the presentation of the statement of comprehensive income is that the only source of information that can measure all value creation done by the company is distinguished by value distribution to the owner (Chambers, Linsmeier, Shakespeare, \& Sougiannis, 2007). Research Biddle and Choi (2006) also support the disclosure of comprehensive income components. His research explained that the different profit definitions would have different information uses for financial statements' users. Comprehensive earnings reporting increased the value relevance of the earnings information. Increasing the value relevance of the $\mathrm{OCl}$ component of the earnings increased its information usefulness in investor decision making.

Psychological-based research has been done through experimental methods by Hirst and Hopkins (1998). In his research, Hirst and Hopkins (1998) stated that information would not be used if it was not available and not ready for processing (not clear). The research's results showed that the income statement and other comprehensive income presentations were useful in improving the transparency of earnings management activities undertaken by management to be more visible, thereby reducing analyst judgment to be equivalent to the judgment level in companies that did not perform earnings management. The results also revealed that other comprehensive income disclosures were more effectively presented on the Statement of Changes in Equity.

Comprehensive income has value relevance for the investor because it measures the company's overall performance, including all transactions that increase the equity other than transactions with the company's owner (Chambers et al. 2007; Biddle \& Choi, 2006). Thus, the first hypothesis tested in this study is:

$\boldsymbol{H}_{1}$ : Other Comprehensive Income has value relevance.

The revised IAS 1's adoption aims to improve the quality of information valuable to investors than before the revision. Following Hirst and Hopkins (1998), Maines and McDaniels (2000) stated that information would be useful if available and ready for processing by the user. Thus $\mathrm{OCl}$, whose presentation location was moved from equity to comprehensive income after adopting revised IAS 1 , then its value relevance is expected to be higher than before the revision. Therefore, this study proposes the second hypothesis: 
$\boldsymbol{H}_{2}$ : The value relevance of the Other Comprehensive Income increases after adopting revised IAS 1: Presentation of Financial Statements.

\section{Research Method}

\section{Data and Sample}

This study employed listed companies in ASEAN 5: Malaysia, Singapore, Philippine, Thailand, and Indonesia and compared the value relevance of the $\mathrm{OCl}$ one year before and after the IAS 1's adoption in each country. Table 1 shows IAS 1's adoption into local accounting standards for each country.

Table 1 IAS 1's adoption in ASEAN Country

\begin{tabular}{|c|c|c|}
\hline Country & Local Accounting Standard & Effective Year \\
\hline Indonesia & PSAK No. 1 & 1 January 2011 \\
\hline Malaysia & MFRS No. 101 & 1 January 2010 \\
\hline Singapore & SFRS No. 1 & 1 January 2009 \\
\hline Philippine & PFRS No. 1 & 1 January 2009 \\
\hline Thailand & TAS No. 1 & 1 January 2011 \\
\hline
\end{tabular}

\section{Hypothesis Testing}

Value-relevance studies aim to assess the extent to which accounting data reflect information that is "relevant" for firm value as represented by the stock price (Holthausen \& Watts, 2001). This study used a model widely employed in the value relevance literature: The Price Regression Model (PRM) from Ohlson Model (1995) with stock price as the dependent variable. Ohlson Model (1995) starts from the assumption that firm value equals the present value of the expected dividend. The underlying idea that stock value (net) corresponds to value creation and distribution. The firm value theory relies on net surplus relationships to identify different roles for each of the three variables: income, book value, and dividends. The essence of the valuation function can be stated that the company value is the weighted average of (i) current income, which is capitalized (adjusted for dividends), and (ii) current book value. The $\mathrm{OCl}$ is part of current income that has to be examined. Therefore, this study would test the hypothesis by inserting the $\mathrm{OCl}$ as current income in the Ohlson Model.

Model 1 was used to examine OCl's value relevance before considering the IAS 1 revision. Meanwhile, model 2 was used to test OCl's value relevance after the IAS 1 revision. Model 1 and Model 2 are stated as follows:

$$
\begin{aligned}
& \text { Price }_{i t}=\beta 0+\beta 1 B V E_{i t}+\beta 2 N I_{i t}+\beta 30 C l_{i t}+e_{i}
\end{aligned}
$$

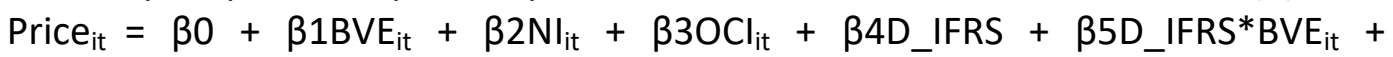

$$
\begin{aligned}
& \beta 6 D \_I F R S * N I_{i t} \beta 7 D \_I F R S^{*} O C_{i t}+e_{i .}
\end{aligned}
$$


Whereas, Price $_{i t}=$ is the stock price on the $31^{\text {st }}$ of March $_{t+1} ; \mathrm{Nl}_{\mathrm{it}}$ is ${ }_{\text {the }}$ Net income per share; $\mathrm{BVE}_{\mathrm{it}}$ is book value per share; $\mathrm{OCl}$ it $=\mathrm{OCl}$ per share. $\mathrm{D}$ IFRS $=1$, in the period of Revised IAS 1, become enacted in each country; Indonesia and Thailand (2011), Philippines and Singapore (2009), and Malaysia (2010) and 0 (zero) in the one year period before the adoption.

If the $\mathrm{OCl}$ presentation has a value relevance for financial statement users, as stated in $\mathrm{H}_{1}$, then it is expected that the $\mathrm{OCl}$ coefficient is positive and significant $(\beta 3>0)$. Moreover, if the IAS 1 revision leads to a higher OCl's value relevance, as stated in $\mathrm{H} 2$, it is expected that the interaction coefficient between dummy IFRS and the $\mathrm{OCI}$ is positive and statistically significant $(\beta 7>0)$. BVE and $\mathrm{NI}$ are also expected to be positively associated with price.

\section{Result and Discussion}

This study collected 46,662 firm years. This study handled the outlier by winsorizing all continuous variables at the $1^{\text {st }}$ and $99^{\text {th }}$ percentiles. As a result, 46,410 firm years were obtained as our final sample.

\section{Statistic Descriptive}

Table 2 provides descriptive statistics for the variables observed. All variables were scaled by common stock outstanding in the fiscal year.

Tabel 2 Statistic Descriptive

\begin{tabular}{lccccc}
\multicolumn{1}{r}{ Variable } & N & Min & Max & Mean & Stdev \\
\hline BE & 46,410 & $-58.065,38$ & 2.545 .152 & 449,857 & $20.017,98$ \\
NI & 46,410 & $-71.942,23$ & $359.241,6$ & 47.072 & $2.104,047$ \\
OCl & 46,410 & $-13.787,47$ & $7.314,871$ & 0,123 & 74,968 \\
D_IFRS*BV & 46,410 & $-58.065,38$ & 2.545 .152 & 372,113 & $19.877,38$ \\
D_IFRS*NI & 46,410 & $-71.942,23$ & $359.241,6$ & 35,582 & $2.066,069$ \\
D_IFRS*OCl & 46,410 & $-13.787,47$ & $2.311,996$ & $-0,050$ & 66,784 \\
\hline
\end{tabular}

\section{Hypotheses testing results}

This study's results are presented in Table 2. Model 1 regression result showed the value relevance of book value of equity, net income, and $\mathrm{OCl}$ without considering IAS 1 implementation. The results revealed that $\mathrm{OCI}$ had a significant positive association with the stock price $(\beta=0,769, p<0,05)$, meaning that $\mathrm{OCl}$ had value relevance on price. Therefore, $\mathrm{H}_{1}$ was supported. The results also showed that the book value of equity had value relevance on price, but the net income was not proven to have value relevance. 
Table 3 Regression Results

\begin{tabular}{|c|c|c|c|c|c|c|c|c|}
\hline \multirow[b]{2}{*}{ Variable } & $\begin{array}{l}\text { Model } \\
\text { Priceit }\end{array}$ & $\begin{array}{c}30+\beta 1 B V \\
\text { sit }\end{array}$ & + B2N & $+\beta 30 \mathrm{Clit}+$ & $\begin{array}{l}\text { Model : } \\
\text { Priceit : }\end{array}$ & $\begin{array}{c}30+\beta 1 B V E \\
+\beta 4 D \_I F \\
\beta 5 D \_ \text {_FR } \\
\text { B6D_IFR } \\
\text { B7D_IFR }\end{array}$ & $\begin{array}{l}\text { B2Nlit } \\
+ \\
\text { VEit }+ \\
\text { Ulit } \\
\text { Clit }+\varepsilon\end{array}$ & B30Clit \\
\hline & Hyp & Coeff & $t$-stat & Prob & Hyp & Coeff & $t$-stat & Prob \\
\hline Const & & 217.192 & 40.67 & 0.000 & & 115.169 & 14.14 & 0.000 \\
\hline BV & & 0.003 & 5.64 & $0.000 * * *$ & & 0.003 & 0.81 & 0.420 \\
\hline NI & & -0.017 & -3.86 & $0.000 * * *$ & & -0.014 & -0.59 & 0.554 \\
\hline $\mathrm{OCl}$ & $\mathrm{H} 1:+$ & 0.769 & 6.81 & $0.000 * * *$ & & -0.162 & -0.99 & 0.321 \\
\hline D_IFRS & & & & & & 180.951 & 16.62 & $\begin{array}{l}0.000 * \\
* *\end{array}$ \\
\hline D_IFRS*BV & & & & & & 0.003 & 0.66 & 0.511 \\
\hline D_IFRS*NI & & & & & & -0.025 & -1.05 & 0.296 \\
\hline D_IFRS*OCI & & & & & $\mathrm{H} 2:+$ & 1.792 & 7.87 & $\begin{array}{l}0.000 * \\
* *\end{array}$ \\
\hline Country & & & Yes & & & & Yes & \\
\hline N (obs) & 46.410 & & & & 46.410 & & & \\
\hline R2 & 0.0011 & & & & 0.0056 & & & \\
\hline F-stat & 16.36 & & & & 34.83 & & & \\
\hline Prob F-stat & 0.000 & & & & 0.000 & & & \\
\hline
\end{tabular}

This result is consistent with Chambers et al. (2007) that the investors are more concerned if $\mathrm{OCl}$ is presented in the Statement of Changes in Equity than in the Income Statement. This finding is different from Mechelli and Cimini (2014) findings, where the results demonstrated that $\mathrm{NI}$ had higher value relevance than $\mathrm{OCl}$. Table 3 presents the results of testing model 1 per each country. The results indicated that net income had a higher value relevance than $\mathrm{OCl}$ in all sample countries except Indonesia. Net income had value relevance in Malaysia, Singapore, and the Philippines. Testing using only the Indonesian sample proved that net income had lower value relevance than $\mathrm{OCl}$. Therefore, model 1 main results, shown in Table 3, are mainly due to the companies' sample in Indonesia.

Model 2 regression result showed the IAS 1 implementation's effect on the value relevance of book value of equity, net income, and $\mathrm{OCl}$. The result revealed, with $\beta=1,792, p<0,05$, the increased value relevance of the OCl after the revision of the IAS 1 . Thus, $\mathrm{H}_{2}$ was supported. It indicated that the comprehensive earnings reporting increased the value relevance and information usefulness in investor decision making. This result is consistent with the results of Biddle and Choi (2006), and Mita, Siregar, and Fitriany (2017) support the disclosure of comprehensive income components. Separate test results by country (refer to Table 3 Model 2 ) uncovered mixed evidence. OCl's value relevance was shown in Indonesia. An increase in OCl's value relevance was only found in Indonesia. The result might be because, before the revised IAS 1 implementation, OCl's value relevance in Indonesia had the lowest value of magnitude (significantly negative) compared to other sample countries. Therefore, when the IAS 1 revision was adopted, it benefited more from the increase of OCl's value relevance than other countries. 
Table 4 Summary of Regression Results by Country

\begin{tabular}{|c|c|c|c|c|c|}
\hline & Indonesia & Malaysia & Singapore & Philipines & Thailand \\
\hline \multicolumn{6}{|c|}{ Model 1: the $\mathrm{OCI}$ has value relevance } \\
\hline BV & + & + & + & + & + \\
\hline $\mathrm{NI}$ & - & + & + & + & $\begin{array}{c}\text { Not } \\
\text { Significant }\end{array}$ \\
\hline $\mathrm{OCl}$ & + & Not Significant & Not Significant & Not Significant & $\begin{array}{c}\text { Not } \\
\text { Significant }\end{array}$ \\
\hline \multicolumn{6}{|c|}{ Model 2: The value relevance of $\mathrm{OCl}$ is increased after the adoption of revised IAS 1} \\
\hline BV & + & + & + & + & - \\
\hline $\mathrm{NI}$ & + & + & Not Significant & - & $\begin{array}{c}\text { Not } \\
\text { Significant }\end{array}$ \\
\hline $\mathrm{OCl}$ & - & Not Significant & Not Significant & Not Significant & $\begin{array}{c}\text { Not } \\
\text { Significant }\end{array}$ \\
\hline D_IFRS*BV & Not Significant & + & - & + & + \\
\hline D_IFRS*NI & - & + & Not Significant & Not Significant & $\begin{array}{c}\text { Not } \\
\text { Significant }\end{array}$ \\
\hline D_IFRS*OCI & + & Not Significant & + & Not Significant & $\begin{array}{c}\text { Not } \\
\text { Significant }\end{array}$ \\
\hline
\end{tabular}

According to Table 4 ,overall, the study's results showed that the IAS 1 implementation increased OCl's value relevance, especially in sample companies in Indonesia. The results also revealed that without considering the IAS 1 implementation, the net income had a higher value relevance compared to $\mathrm{OCl}$ in all sample countries, except for Indonesia and Thailand.

This study also performed a sensitivity analysis for the stock price on $31^{\text {st }}$ December ${ }_{t+1}$ and found similar results (Table is not shown). The regression result disclosed a consistent result with the main test. There was a positive and significant association between the $\mathrm{OCl}$ and price. The $\mathrm{OCl}$ had a higher positive coefficient, meaning higher value relevance after the IAS 1 revision.

\section{Discussion}

The financial statements' presentation, according to IAS 1, requires $\mathrm{OCI}$ to be included in the statement of companies' performance, i.e., Statement of Comprehensive Income. Therefore, the location of the $\mathrm{OCl}$ presentation is matters for investors. It supports the view that IFRS adoption improves financial statements' quality, in this case, increases $\mathrm{OCl}^{\prime} \mathrm{s}$ value relevance. This result is consistent with prior research, such as Chambers et al. (2007); Biddle and Choi (2006); Khan and Bradbury (2014).

The $\mathrm{OCl}$ reporting in a single statement in the comprehensive income statement makes the investors easier in analyzing the companies' performance. The items presented as the bottom line are ready to use and summarize all companies' performance for the period. Investors, obviously, want a financial statement that can portray the economic condition of related firms. Thus, the investor will quickly examine the presentation of the earnings and OCl's components and reward those firms with their trust that reflected on the company's stock price. Based on Kanagaretnam, Mathieu, and Shehata 
(2009), other comprehensive income components are associated with the firm performance summarized in stock price. When the $\mathrm{OCl}$ is increased, the stock price is also increased. The results indicated that the investors used the information about $\mathrm{OCl}$ as their assessment basis.

This study's result aligns with Khan and Bradbury (2014) that there was an increase in OCl's value relevance after the IAS 1 revision. This study confirmed the phenomena that the location of the $\mathrm{OCl}$ information's presentation is matters. Investors and analysts will be easier to analyze the $\mathrm{OCl}$ if the $\mathrm{OCl}$ items are reported after net income in a single statement. It can also help a new investor who barely has the experience to analyze all financial statements' details. It is why the location of OCI presentation, according to IAS 1 , had higher value relevance.

\section{Conclusion}

This study examines whether OCl's value relevance has been increased after revised IAS 1. Extending the literature on the $\mathrm{OCl}$ usefulness and its reporting location, the results found that adopting IAS 1 revision led to higher-value relevance of the $\mathrm{OCI}$.

This result provides empirical evidence about the impact of adopting revised accounting standards as feedback on the IFRS convergence process conducted by the Financial Accounting Standards Board in each ASEAN member country. Our findings also imply that IFRS convergence is beneficial for investors. Improving the financial statements' quality is essential in realizing the capital markets' integration in ASEAN.

The study result has to be considered with some limitations. This study only focused on total OCI. The study did not analyze the impact of adopting IAS 1 revision in each item of $\mathrm{OCl}$, such as available for sale component, revaluation surplus, or translation component. Another thing to elaborate in the future study is the impact of adopting IAS 1 revision in each 5 (five) countries. OCl's value relevance in each country may not be the same. It depends on some factors, such as legal title in that country. It will be interesting if the future study can analyze the differences in the impact in IAS 1 revision.

\section{Acknowledgments}

We gratefully acknowledge financial support from the Research Grant of the Ministry of Higher Education in Indonesia.

\section{References}

Biddle, G., \& Choi, J. H. (2006). Is comprehensive income useful? Journal of Contemporary Accounting \& Economics, 2(1), 1-32. https://doi.org/10.1016/s1815-5669(10)70015-1 
Chambers, D., Linsmeier, T.J., Shakespeare, C., \& Sougiannis, T. (2007). An Evolution of SFAS No. 130 Comprehensive Income Disclosure. Review Accounting Study, 12, 557593. https://doi.org/10.1007/s11142-007-9043-2

Goncharov, I., \& Hodgson, A. (2011). Measuring and reporting income in Europe. Journal of International Accounting Research, 10(1), 27-59. https://doi.org/10.2308/iiar.2011.10.1.27

Hirst, D. E., \& Hopkins, P.E. (1998). Comprehensive Income Disclosures and Analysts' Valuation Judgments. Journal of Accounting Research, 36, 47-75. https:// doi.org/10.2307/2491306

Holthausen, R. W., \& Watts, R. L. (2001). The relevance of the value-relevance literature for financial accounting standard setting. Journal of Accounting and Economics, 31(1-3), 3-75. https://doi.org/10.1016/s0165-4101(01)00029-5

Jones, D. A., \& Smith, K. J. (2011). Comparing the value relevance, predictive value, and persistence of other comprehensive income and special items. The Accounting Review, 86(6), 2047-2073. https://doi.org/10.2308/accr-10133

Kanagaretnam, K., Mathieu, R., \& Shehata, M., (2009). Usefulness of Comprehensive Income Reporting in Canada. Journal of Accounting Public Policy, 28, 349-465. https://doi.org/10.1016/i.jaccpubpol.2009.06.004

Khan, S., \& Bradbury, M. E. (2014). Volatility and risk relevance of comprehensive income. Journal of Contemporary Accounting \& Economics, 10(1), 76-85. https://doi.org/10.1016/i.jcae.2014.01.001

Maines, L. A., \& McDaniel, L. S. (2000). Effects of comprehensive income characteristics on nonprofessional investors' judgments: The role of financial statement presentation format. The Accounting Review, 75(2), 179-207. https://doi.org/10.2308/accr.2000.75.2.179

Mechelli, A., \& Cimini, R. (2014). Is comprehensive income value relevant and does location matter? A European study. Accounting in Europe, 11(1), 59-87. https://doi.org/10.1080/17449480.2014.890777

Mita, A. F., Siregar, S. V. N. P., \& Fitriany (2017). Income (OCI) in Indonesia. International Journal of Applied Business and Economic Research, 15(20), 133-152. Retrieved from https: $/ /$ www.google.com/url? sa $=t \& r c t=j \& q=\& e s r c=s \&$ source $=$ web \&cd $=\& c a d=$ rja $\underline{\text { \&uact }}=8 \& v e d=2$ ahUKEwirkeqfvc TrAhWMbisKHZa7CH8QFjAAegQIARAB\&url= https $\% 3 \mathrm{~A} \% 2 \mathrm{~F} \% 2 \mathrm{Fsch}$ olar.ui.ac.id $\% 2 \mathrm{Fen} \% 2 \mathrm{Fpublications} \% 2$ Fincome-oci-inindonesia\&usg= $=\mathrm{AOvVaw} 05 \mathrm{Ip} 5 \mathrm{y} 6 \mathrm{AU} 6 \mathrm{k}$ iswxBIk6ag

Ohlson, J. A. (1995). Earnings, Book Values, and Dividends in Equity Valuation. Contemporary Accounting Research, 11(2), 661-687. https://doi.org/10.1111/j.19113846.1995.tb00461.x 